\title{
The evaluation of the therapeutic potential of hesperetin on diethylnitrosamine and phenobarbital induced liver injury in rats
}

\author{
Mehmet Ali KISAÇAM ${ }^{1, a, ~} ₫$, Gonca Ozan KOCAMÜFTÜOĞLU ${ }^{2, b}$, Nalan Kaya TEKTEMUR ${ }^{3, c}$, \\ Sema Temizer OZAN ${ }^{4, d}$
}

\begin{abstract}
${ }^{1}$ Department of Biochemistry, Faculty of Veterinary Medicine, Mustafa Kemal University 31060, Hatay, Turkey; ${ }^{2}$ Department of Biochemistry, Faculty of Veterinary Medicine, Mehmet Akif Ersoy University 15030, Burdur, Turkey; ${ }^{3}$ Department of Histology and Embryology, Faculty of Medicine, Firat University 23119, Elazig, Turkey, ${ }^{4}$ Department of Biochemistry, Faculty of Veterinary Medicine, Firat University 23119, Elazig, Turkey

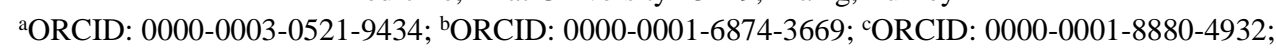

dORCID: 0000-0002-2274-1999
\end{abstract}

${ }^{\square}$ Corresponding author: mehmetalikisacam@ mku.edu.tr
Received date: 20.10 .2020 - Accepted date: 15.06 .2021

\begin{abstract}
Nitrite and amine reactions can occur rapidly and produce nitrosamines, in-vivo. Diethylnitrosamine (DEN) and phenobarbital (PB) are readily inducing liver injury and hesperetin (HES), as a flavonoid found in citrus fruits, have the potential to compensate for their harmful effects. In this study, the therapeutic effects of HES were evaluated in DEN and PB mediated liver defect. Adult male Sprague-Dawley rats were split into 5 groups $(\mathrm{n}=10)$ : Control, DEN, DEN+PB, HES, and DEN+PB+HES. 150 mg/kg DEN was applied intraperitoneally to DEN groups. Fifteen days after the DEN application 500ppm of PB was given in drinking water. HES were administered at $50 \mathrm{mg} / \mathrm{kg}$ dose orally for 8 weeks. Blood and liver malondialdehyde (MDA), glutathione (GSH) levels, and catalase (CAT), superoxide dismutase (SOD) activities were measured spectrophotometrically. Moreover, histologic examination of liver sections and apoptosis were determined with hematoxylin-eosin and TUNEL methods, respectively. DEN-PB application was found to increase blood and liver MDA levels and liver CAT activity, oppositely, decreased blood and liver SOD activity, GSH levels, and blood CAT activity. HES was found to have a positive impact on oxidative stress parameters by decreasing liver and blood MDA activity, increasing blood CAT and SOD activity together with liver GSH levels and SOD activity. Whereas DEN and PB application increased all histopathological findings and TUNEL positive cells, HES administration decreased these findings which might be important for the protection of liver cell structure from cell damage. These results suggest that HES administration could be an alternative therapeutic approach to liver damage.
\end{abstract}

Keywords: Apoptosis, diethylnitrosamine, hesperetin, oxidative stress, phenobarbital.

\section{Hesperetin'in, sıçanlarda dietilnitrozamin ve fenobarbital kaynaklı karaciğer hasarı üzerindeki terapötik potansiyelinin değerlendirilmesi}

\footnotetext{
Özet: Nitrit ve amin reaksiyonları hızla meydana gelir ve in-vivo olarak nitrozaminler üretir. Dietilnitrosamin ve fenobarbital kolayca karaciğer hasarına neden olur ve turunçgillerde bulunan bir flavonoid olan Hesperetin (HES) bu zararlı etkileri telafi etme potansiyeline sahiptir. Bu çalışmada, HES'in tedavi edici etkileri DEN ve PB ile oluşturulan karaciğer hasarında değerlendirildi. Yetişkin erkek Sprague-Dawley sıçanlar 5 gruba $(n=10)$ ayrıldı: Kontrol, DEN, DEN+PB, HES ve DEN+PB+HES. DEN gruplarına $150 \mathrm{mg} / \mathrm{kg}$ DEN intraperitoneal olarak uygulandı. DEN uygulamasından 15 gün sonra DEN+FB grubu ve DEN+FB+HES gruplarına, içme suyu içerisinde 500 ppm FB verildi. HES ve DEN+PB+HES grupları, 8 haftalık deney sırasında $50 \mathrm{mg} / \mathrm{kg}$ HES oral olarak uyguland. Kan ve karaciğer MDA, GSH seviyeleri ve CAT, SOD aktiviteleri spektrofotometrik olarak ölçüldü. Ayrıca karaciğer kesitlerinin histolojik incelemesi ve apoptoz sırasıly Hematoksilen-eozin ve TÜNEL yöntemleriyle belirlendi. DEN ve PB uygulamasının, karaciğer CAT aktivitesi ile birlikte kan ve karaciğer MDA seviyelerini arttırdığı, bunun aksine, kan ve karaciğer SOD aktivitesini, GSH seviyelerini ve kan CAT aktivitesini azalttığı belirlendi. HES'in oksidatif stres parametreleri üzerine, hem karaciğer hem de kan MDA aktivitesini azaltarak, ayrıca karaciğer glutatyon seviyeleri ve SOD aktivitesi ile birlikte kan katalaz ve SOD aktivitesini artırarak olumlu bir etkisi olduğu bulunmuştur. DEN ve PB uygulaması tüm histopatolojik bulguları ve tünel pozitif hücreleri artırırken, bunun tersine HES uygulaması, karaciğer hücre yapısının hücre hasarından korunması için önemli olabilecek bu bulguları azaltmıştır. $\mathrm{Bu}$ sonuçlar, HES uygulamasının karaciğer hasarına karşı alternatif bir terapi yaklaşımı olabileceğini düşündürmektedir.
}

Anahtar sözcükler: Apopitoz, dietilnitrozamin, hesperetin, oksidatif stres, fenobarbital. 


\section{Introduction}

Nitrosamines may present in cigarettes, alcoholic beverages, smoked seafood, processed meat products, and generated in foods by a reaction that occurs between amines and nitrite $(7,13,26,27,29)$. Nitrite is used to preserve processed meat products from the generation of clostridium toxins (26). For this reason, processed meat products and other products as well, may contain high nitrosamine content which can be hazardous due to the ROS forming capacity (26). Moreover, DEN, which is a nitrosamine compound, has been indicated to be produced in stomach due to the activity of some bacteria in acidic condition $(26,35)$. The animal experiments revealed that DEN application cause liver and other organ damages (29, $30,35)$. Histologic evaluation of animals treated with DEN was demonstrated to cause inflammatory cell infiltration, bi-nucleated cells, and sinusoidal dilatation in the liver $(33,35)$. These features are the reason for using DEN to initiate experimental liver damage $(7,36)$. PB, on the other hand, promotes liver cell proliferation and tumor formation following DEN administration and together with DEN are widely used agents in liver toxicity and tumor studies, as initiators and promoters $(38,45)$. Oxidative stress is regarded as one of the leading cause of the majority of the liver disorders (5). ROS forming capacity of DEN can be detrimental due to the accumulation of ROS in liver cells, which further might stimulate cell death $(27,30,36)$. ROS accumulation in the liver cell causes a deficiency of antioxidant such as GSH (30). Disrupted balance between oxidant and antioxidant result with oxidative stress $(42,47)$. Counteracting oxidative stress via potential antioxidant may have beneficial effects on DEN and PB induced liver damage (40).

Nitrosamine exposure either directly with consumed food or indirectly via the reaction occurs in body indicates that avoiding intake of nitrosamines is highly challenging. Instead of avoiding its intake, reducing its strength may be more effective. Growing attention has been paid to evaluate the effects of the phytochemicals as therapeutic agents (13). Flavonoids attract the attention of scientists due to major antioxidant capacity (10). HES is one of the most important flavonoids that exists in citrus fruits, possesses antioxidant, antiapoptotic, and anticancer properties $(10,16,25,32)$. Lipophilic feature of HES provide facile entrance to the cells, and just as other flavonoids, HES presents in blood as sulfate conjugate (14). All these features may be important for contributing antioxidant potential of HES. In this concept, the present study purposed to evaluate the therapeutic effects of HES on DEN-PB induced liver defect in rats.

\section{Materials and Methods}

Chemicals and reagents: DEN (CAS No: 55-18-5), PB (CAS No: 50-06-6), Trichloroacetic acid (CAS No:
76-03-9), 2-Thiobarbituric acid (CAS No: 504-17-6), 5,5'Dithiobis-2-nitrobenzoic acid (CAS No: 69-78-3), nitrobluetetrazolium (NBT) (CAS No: 298-83-9), Hydrogen Peroxide (CAS No: 7722-84-1) were purchased from Sigma-Aldrich (St . Louis MO, USA).

Experimental design: Fifty adult male approximately $220 \pm 20 \mathrm{~g}$ weight, Sprague-Dawley rats were utilized in this study. Standard pellet diet and tap water were ad libitum given to the animals. Subjects were divided into 5 groups as control, DEN, HES, DEN+PB, and $\mathrm{DEN}+\mathrm{PB}+\mathrm{HES}$ group. The control group was provided with standard diet and received tap water for 8 weeks. DEN, DEN+PB and DEN+PB+HES groups were intraperitoneally (i.p.) injected with $150 \mathrm{mg} / \mathrm{kg}$ DEN (21). Subsequently, DEN+PB and DEN+PB+HES groups were given 500 ppm PB in drinking water for 6 weeks in pursuit of the DEN application (20). DEN+PB+HES and HES groups received HES at a dose of $50 \mathrm{mg} / \mathrm{kg} /$ day by oral gavage during 8 weeks experimental procedure (2). Following the 8 weeks experimental period, blood samples were taken from the heart under the anesthesia subsequently the rats were euthanized and liver samples were collected.

Blood sample preparation: Blood samples were taken into ethylene diamine tetraacetic acid containing sample tubes (two tubes for each subject). The first blood sample containing tube was kept for whole blood analyses. The second was centrifuged for 5 minutes at $3500 \mathrm{rpm}$ (Nuve NF800R); plasma was taken and maintained at $80^{\circ} \mathrm{C}$ until analyses. The red blood cell suspension in the bottom of the second tube were washed thrice with $0.9 \%$ $\mathrm{NaCl}$ and kept at $-80^{\circ} \mathrm{C}$ before used. MDA and GSH levels together with CAT and SOD activities were evaluated spectrophotometrically.

Liver sample preparation: Liver tissues were cleaned in $0.9 \% \mathrm{NaCl}$ for biochemical analysis and kept at $-80^{\circ} \mathrm{C}$. Tissue homogenization was made in Potterelvehjem homogenizer by using $1.15 \% \mathrm{KCl}$ containing buffer to have 1/10 (weight/volume) final volume of whole homogenate. The whole homogenate were centrifuged at $3500 \mathrm{rpm}$ for 15 minutes to analyze MDA, GSH levels and CAT, SOD activities. MDA and GSH levels also CAT and SOD activities were evaluated spectrophotometrically in liver tissues.

Liver and blood sample analyzes: MDA were assayed in the taken plasma and homogenate, according to the modified method of Placer et al. (28). This method is based on the adduction of thiobarbituric acid with MDA which is one of the aldehyde products of lipid peroxidation and the formation of pink complex (28). The absorbance values of MDA (plasma and liver) were determined according to the pink complex generated. The MDA levels were read at $532 \mathrm{~nm}$ and expressed as $\mathrm{nmol} / \mathrm{mL}$ and $\mathrm{nmol} / \mathrm{g}$ respectively in plasma and liver tissues. 
GSH levels were determined in the whole blood which was diluted with purified water before the analyzes and also in liver tissue supernatant according to the method described by Chavan et al. (9). Briefly, GSH levels were determined with the reaction which cause the formation of the yellow color following the addition of 5,5'-Dithiobis-2-nitrobenzoic acid (DTNB). Subsequently, yellow color formed in the samples was read at $412 \mathrm{~nm}$. GSH levels were expressed as $\mu \mathrm{mol} / \mathrm{g} \mathrm{Hb}$ and $\mu \mathrm{mol} / \mathrm{g}$ protein respectively in the whole blood and liver tissues.

The liver tissues supernatant and washed erythrocytes were diluted with deionized water and used for SOD activity determinations. SOD activity was measured according to a reaction based on blue color formation which occurs as a result of the conversion of nitrobluetetrazolium (NBT) to formazan with the activity of xanthine-xanthine oxidase system. The exhibited blue color was measured at $560 \mathrm{~nm}$. SOD enzyme activity was expressed as $\mathrm{U} / \mathrm{g} \mathrm{Hb}$ and $\mathrm{U} / \mathrm{g}$ protein respectively in diluted erythrocytes and liver tissues (39).

Washed erythrocytes were diluted with deionized water first and then were diluted with phosphate buffer (50mM, pH:7) for CAT activity determinations. Liver tissues supernatant were diluted with phosphate buffer (50mM, pH:7) for CAT activity determinations. CAT activity was measured in diluted erythrocytes and liver tissues supernatant according to Aebi method (1). Aebi method is based on the consumption of $\mathrm{H}_{2} \mathrm{O}_{2}$ by CAT enzyme activity at $240 \mathrm{~nm}$ wavelength. CAT enzyme activity was expressed as katal $(\mathrm{k}) / \mathrm{g} \mathrm{Hb}$ and $\mathrm{k} / \mathrm{g}$ protein respectively in diluted erythrocytes and liver tissues.

Histological evaluation: The liver tissue samples were fixed in $10 \%$ formaldehyde for about 24 hours for histological analysis. Upon fixation was done, the tissues were embedded in paraffin blocks and the blocks were cut into 5-6 $\mu \mathrm{m}$ thickness. The tissue sections were stained with hematoxylin eosin (H\&E) (11). Four parameters of liver injury 1-double nucleated hepatocyte numbers, 2congestion, 3-inflammatory cell infiltration and 4sinusoidal dilation the severity were semi-quantitatively evaluated. These parameters were scored as $0=$ absent, $1=$ weak, $2=$ moderate and $3=$ strong for each parameter (18).

TUNEL assay: The tissues were fixed in $4 \%$ paraformaldehyde and embedded in paraffin, then cut into serial 5-6 $\mu \mathrm{m}$-thick sections and placed on poly-L-lysine coated glass slides. ApopTag Plus Peroxidase, Apoptosis Detection Kit (S7101) was used for the determination of apoptotic cells following the manufacturer's guideline. Sections were visualized with 3, 3-diaminobenzidine tetra hydrochloride (DAB) and counterstained with Harris hematoxylin. TUNEL positive cells and total cells were counted from number of randomly selected fields at 200x magnification from each section under light microscopy (Novel N 800 M).
In each microscopic field of view, 500 cells were counted in 20 randomly selected fields. Counted brown and blue nuclei stained cell number used to calculate apoptotic index and this index was given as the ratio of the TUNEL - positive (brown stained nuclei cells) cell number to the total cell number (brown and blue stained cells) (18).

Statistical analyses: Descriptive statistics presented as mean \pm standard error for continuous variable. The homogeneity assumption was checked with Levene test and the normality assumption was tested with ShapiroWilks test and the coefficient of variation. As all of the continuous dependent variables are violated the homogeneity and normality assumption, Kruskal Wallis test was performed in order to indicate the difference among the five experimental groups. In case any statistical difference, Mann-Whitney U test with Bonferroni correction were used as post-hoc tests. Values less than 0.05 are considered to be statistically significant. All statistical analyses were performed by using IBM SPSS Statistics for Windows, Version 22.0.

\section{Results}

Compared to control, DEN and PB application remarkably increased blood and liver MDA levels $(\mathrm{P}<0.05)$. While blood CAT activity decreased in $\mathrm{DEN}+\mathrm{PB}$ group, liver CAT activity increased significantly. DEN administration followed by PB treatment resulted with decreased GSH levels both in blood and liver. Blood SOD activity decreased approximately two fold, while liver SOD activity statistically remained unchanged (Table 1, 2).

Compared to DEN+PB group, HES administration decreased blood and liver MDA levels significantly in $\mathrm{DEN}+\mathrm{PB}+\mathrm{HES}$ groups $(\mathrm{P}<0.05)$. While blood CAT activity increased significantly in DEN+PB+HES group $(\mathrm{P}<0.01)$, the increase in liver CAT activity was not statistically significant $(\mathrm{P}>0.05)$. Although, blood GSH levels remained unchanged in $\mathrm{DEN}+\mathrm{PB}+\mathrm{HES}$ group, liver GSH levels increased significantly $(\mathrm{P}<0.05)$. Both blood and liver SOD activity increased in DEN+PB+HES group $(\mathrm{P}<0.05$, Table 1, 2). Hepatocytes in liver of control group were normal in histological appearance (Figure 1A).

DEN administration caused sinusoidal dilatation and an increasing number of double nucleated hepatocytes in the periportal area. Additionally, in the same area pronounced inflammatory cells together with mild congestion have been observed (Figure 1B). Compared to the DEN group, PB addition turned out to increase all histopathological findings and the number of large nucleated hepatocytes in the DEN+PB group (Figure 1C). In the DEN+PB+HES group a decrease was observed in all histopathologic changes especially in terms of sinusoidal changes and congestion (Figure 1D and E). Histological changes were not observed in liver of HES 
group compared to that of control group (Figure 1F). Histological scores were shown in Table 3.

TUNEL examination revealed that the number of TUNEL positive cells significantly increased in the DEN and $\mathrm{DEN}+\mathrm{PB}$ groups compared to the control group (Figure 2). Moreover, a significant decrease was observed in the TUNEL positive cell number of DEN+PB+HES group compared to $\mathrm{DEN}+\mathrm{PB}$ group $(\mathrm{P}<0.05$, Table 4$)$.

Table 1. Effects of Hesperetin on blood/erythrocytes/plasma antioxidants enzymes, glutathione (GSH) and malondialdehyde (MDA) levels in DEN+PB induced liver damage in rats.

\begin{tabular}{|c|c|c|c|c|c|}
\hline \multirow{2}{*}{ Items } & \multicolumn{5}{|c|}{ Groups } \\
\hline & Control & DEN & DEN+PB & HES & DEN+PB+HES \\
\hline MDA (nmol/ml plasma) & $10.39 \pm 0.45^{\mathrm{b}}$ & $10.11 \pm 0.69^{\mathrm{b}}$ & $12.51 \pm 0.73^{\mathrm{a}}$ & $5.79 \pm 0.13^{c}$ & $10.40 \pm 0.13^{\mathrm{b}}$ \\
\hline CAT $(\mathrm{k} / \mathrm{g} \mathrm{Hb})$ & $66.43 \pm 8.23^{\mathrm{a}}$ & $69.24 \pm 5.57^{\mathrm{a}}$ & $40.75 \pm 3.89^{\mathrm{b}}$ & $67.54 \pm 7.52^{\mathrm{a}}$ & $77.41 \pm 3.58^{\mathrm{a}}$ \\
\hline GSH $(\mu \mathrm{mol} / \mathrm{g} \mathrm{Hb})$ & $62.77 \pm 4.69^{\mathrm{b}}$ & $40.84 \pm 3.80^{c}$ & $45.20 \pm 3.62^{\mathrm{c}}$ & $76.14 \pm 4.64^{\mathrm{a}}$ & $47.77 \pm 4.32^{\mathrm{bc}}$ \\
\hline SOD (U/g Hb) & $94.11 \pm 14.17^{\mathrm{a}}$ & $78.50 \pm 7.42^{\mathrm{ab}}$ & $56.85 \pm 4.66^{\mathrm{b}}$ & $95.13 \pm 3.15^{\mathrm{a}}$ & $108.34 \pm 5.61^{\mathrm{a}}$ \\
\hline
\end{tabular}

* The data presented as means and standard error.

*a,b,c: Values with different letters in the rows indicates statistically difference between groups $(\mathrm{P}<0.05)$.

Table 2. Effects of Hesperetin on liver antioxidants enzymes, glutathione (GSH) and malondialdehyde (MDA) levels in DEN+PB induced liver damage in rats.

\begin{tabular}{llllll}
\hline \multirow{2}{*}{ Items } & \multicolumn{5}{c}{ Groups } \\
\cline { 2 - 6 } & Control & DEN & DEN+PB & HES & DEN+PB+HES \\
\hline Liver MDA (nmol/g tissue) & $21.06 \pm 0.42^{\mathrm{d}}$ & $29.44 \pm 0.68^{\mathrm{b}}$ & $64.06 \pm 1.2^{\mathrm{a}}$ & $25.63 \pm 0.46^{\mathrm{c}}$ & $26.94 \pm 1.33^{\mathrm{bc}}$ \\
Liver CAT (k/g protein) & $175.21 \pm 5.45^{\mathrm{cd}}$ & $148.32 \pm 4.29^{\mathrm{d}}$ & $196.17 \pm 2.51^{\mathrm{bc}}$ & $277.56 \pm 15.08^{\mathrm{a}}$ & $210.65 \pm 3.51^{\mathrm{b}}$ \\
Liver GSH ( $\boldsymbol{\mu \text { mol} / \mathbf { g } \text { protein) }}$ & $627.82 \pm 10.23^{\mathrm{c}}$ & $544.61 \pm 19.07^{\mathrm{d}}$ & $485.54 \pm 7.90^{\mathrm{d}}$ & $1185.23 \pm 12.47^{\mathrm{b}}$ & $1045.77 \pm 24.78^{\mathrm{a}}$ \\
Liver SOD (U/g protein) & $117.50 \pm 2.98^{\mathrm{b}}$ & $107.39 \pm 3.33^{\mathrm{b}}$ & $112.23 \pm 5.45^{\mathrm{b}}$ & $151.54 \pm 2.17^{\mathrm{a}}$ & $146.14 \pm 1.11^{\mathrm{a}}$ \\
\hline
\end{tabular}

* The data presented as means and standard error.

*a,b,c: Values with different letters in the rows indicates statistically difference between groups $(\mathrm{P}<0.05)$.
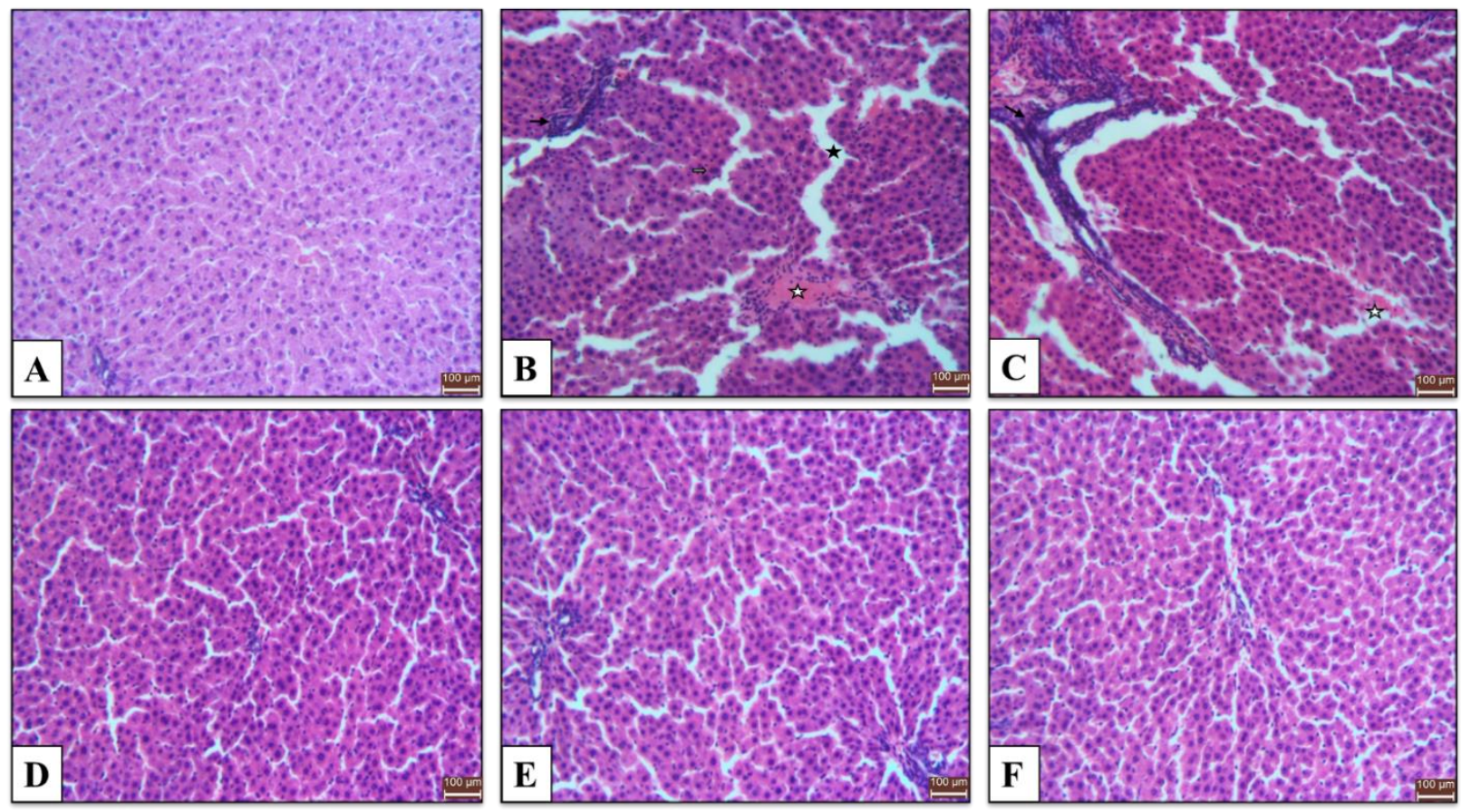

Figure 1. Hesperetin Effect on Liver Histopathology of diethylnitrosamine and phenobarbital induced damage in rats. A: Control group. Normal hepatocytes and sinusoids.

B: DEN group. Sinusoidal dilation (black star), inflammatory cell infiltration in periportal area (black arrow), congestion (white star) and double nucleated hepatocytes (white arrow).

C: DEN + PB group. Inflammatory cell infiltration in periportal area (black arrow) and congestion (white star).

D and E: DEN + PB + HES group. All histopathological changes, especially sinusoidal dilatation and congestion, were decreased.

F: The HES group. Normal hepatocytes and sinusoids. H \& E x200. 

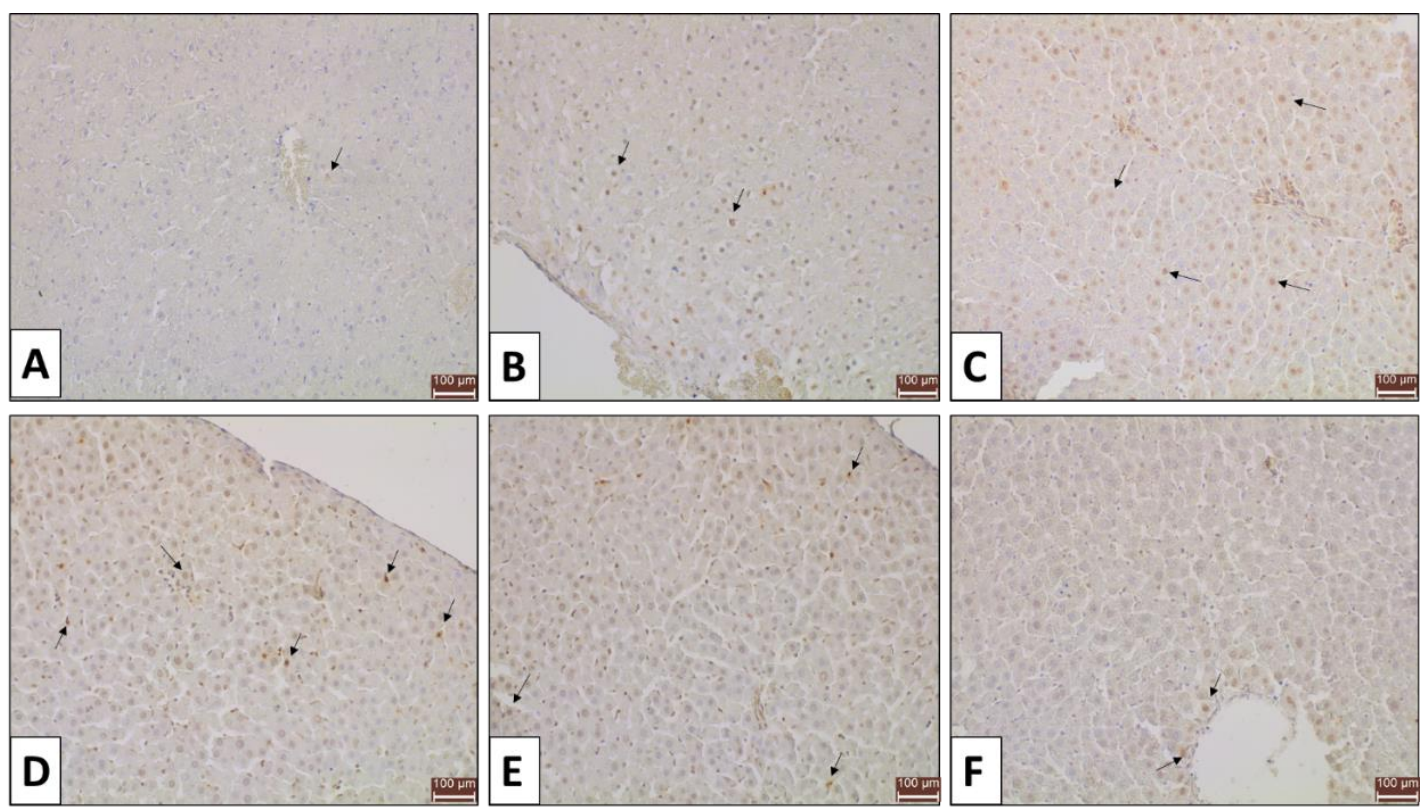

Figure 2. Hesperetin effect on Liver Apoptosis Index of diethylnitrosamine and phenobarbital induced damage in rats. Comparison of TUNEL positivity (brown nucleus) among groups.
Control (A)
DEN (B)
$\mathrm{DEN}+\mathrm{PB}(\mathrm{C}, \mathrm{D})$
$\mathrm{DEN}+\mathrm{PB}+\mathrm{HES}(\mathrm{E})$
HES (F)

Table 3. Effects of Hesperetin on Liver Histopathology of diethylnitrosamine and phenobarbital induced damage in rats.

\begin{tabular}{lllll}
\hline Groups & $\begin{array}{l}\text { Increase of Double Nucleated } \\
\text { Hepatocyte Numbers }\end{array}$ & Congestion & $\begin{array}{l}\text { Inflammatory Cell } \\
\text { Infiltration }\end{array}$ & $\begin{array}{l}\text { Sinusoidal } \\
\text { Dilation }\end{array}$ \\
\hline Control & $0.40 \pm 0.54^{\mathrm{b}}$ & $0.40 \pm 0.54^{\mathrm{b}}$ & $0.20 \pm 0.44^{\mathrm{b}}$ & $0.20 \pm 0.44^{\mathrm{b}}$ \\
DEN & $2.00 \pm 0.70^{\mathrm{a}}$ & $2.00 \pm 0.00^{\mathrm{a}}$ & $1.80 \pm 0.44^{\mathrm{a}}$ & $1.60 \pm 0.54^{\mathrm{a}}$ \\
DEN+PB & $3.00 \pm 0.00^{\mathrm{a}}$ & $2.80 \pm 0.44^{\mathrm{a}}$ & $2.80 \pm 0.44^{\mathrm{a}}$ & $2.60 \pm 0.54^{\mathrm{a}}$ \\
DEN+PB+HES & $1.00 \pm 0.70^{\mathrm{b}}$ & $1.00 \pm 0.70^{\mathrm{b}}$ & $1.00 \pm 0.70^{\mathrm{b}}$ & $0.40 \pm 0.54^{\mathrm{b}}$ \\
HES & $0.60 \pm 0.54^{\mathrm{b}}$ & $0.60 \pm 0.54^{\mathrm{b}}$ & $0.40 \pm 0.54^{\mathrm{b}}$ & $0.40 \pm 0.54^{\mathrm{b}}$ \\
\hline
\end{tabular}

* Values are means \pm standard deviation. ${ }^{\mathrm{a}} \mathrm{P}<0.05$ Control vs. all group. ${ }^{\mathrm{b}} \mathrm{P}<0.05 \mathrm{DEN}+\mathrm{FB}$ vs. all group.

Table 4. Effects of Hesperetin on liver apoptotic index (\%) in DEN+PB induced liver damage in rats.

\begin{tabular}{cccccc}
\hline \multirow{2}{*}{ Item } & \multicolumn{5}{c}{ Groups } \\
\cline { 2 - 6 } & Control & DEN & DEN + PB & HES & DEN+PB+HES \\
\hline Apoptotic Index (\%) & $4.8 \pm 2.73$ & $18.4 \pm 3.12^{\mathrm{ab}}$ & $25.2 \pm 3.15^{\mathrm{a}}$ & $7.2 \pm 1.55^{\mathrm{ab}}$ & $9.83 \pm 2.84^{\mathrm{ab}}$ \\
\hline
\end{tabular}

* Values are means \pm standard deviation. ${ }^{\mathrm{a}} \mathrm{P}<0.05$ Control vs. all group. ${ }^{\mathrm{b}} \mathrm{P}<0.05 \mathrm{DEN}+\mathrm{FB}$ vs. all group.

\section{Discussion and Conclusion}

PB promotion after a sub chronic DEN administration is a widely used model in the liver carcinogenesis studies $(43,45)$. DEN, PB, and their metabolites cause toxicity by inducing the production of ROS, which in return lead to liver and erythrocyte peroxidation (45). Moreover, DEN and PB exposure have been shown to increase lipid peroxidation in rats $(35,43)$. Consistently with the previous studies, enhanced levels of MDA have been observed in the current study, after DEN and PB application. High MDA levels are widely regarded as an indicator of lipid peroxidation, which occurs due to the surplus generation of ROS (35). Decreased MDA levels after HES administration in the present study both in liver and erythrocytes may be related to the antioxidant properties of HES. A large body of evidence proposes that flavonoids participate in the detoxification process of ROS related damage $(10,16)$. Revealed properties might arise from the hydrogen donating capacity of flavonoids to reactive substances $(8,22,31)$ Moreover, lipophilic features of HES might contribute to the protection of membrane lipids from oxidation and might cause a decrease in MDA levels, which, in turn, might be beneficial for liver therapy.

Shaban et al. (35) found an increase in the number of bi-nucleated cells in rats treated with DEN and PB. In another study DEN and PB were showed to induce inflammatory infiltrate (33). Consistent with these studies $(33,35)$, in our study double nucleated hepatocytes, inflammatory cells, and mild congestion were determined 
to increase, which might be the result of macrophages activation due to DEN and PB stimulated ROS generation. In a recent study demonstrating the effects of HES on hepatic injury in rats, HES was found to improve hepatocyte architecture (12). Similarly, in our study HES was showed to improve hepatocellular architecture in $\mathrm{DEN}+\mathrm{PB}+\mathrm{HES}$ group. Improvement in hepatocytes structure following HES treatment might probably be related to the antioxidant effects of HES.

SOD and CAT are two important antioxidant enzymes responsible for radical scavenging activity (10). SOD, which stands as the first enzymatic defense line against cellular oxidation, is responsible for the conversion of superoxide radicals to hydrogen peroxide. Subsequently, hydrogen peroxide is decomposed to water and oxygen by CAT activity (37). DEN and PB application have been reported to increase superoxide radical generation and solely DEN application has been shown to decrease liver SOD activity (15). Owumi et al (23) reported that DEN administration to 5 weeks old Wistar rats resulted in decreased SOD activity as well. Oppositely, Hussein et al. (19) indicated that SOD activity did not change significantly after the 24 week of the DEN and $\mathrm{PB}$ administration. In accordance with the previous studies $(19,23)$; DEN administration followed by PB decreased blood SOD activity in the current study, while liver SOD activity remained unaltered as Hussein et al. (19) reported. Decreased blood and unaltered liver SOD levels might indicate the imbalance between oxidants and antioxidants. Moreover, these findings might suggest that oxidation in blood has been initiated before that of the liver. Antioxidant defense system is crucial to prevent the deleterious effects of oxidants. SOD and CAT which are two antioxidant enzymes, protect cell membranes from integrity loss. In a study evaluating the effects of HES on DEN induced hepatocarcinoma, it was found that HES increased SOD levels compared to DEN administered group (17). Besides, HES has been reported to increase SOD expressions in mice treated with DMBA (10). These studies disclosed the positive impact of HES on SOD levels. In line with these studies $(10,17)$, we found that HES increased both blood and liver SOD activities. The aforementioned connection of two antioxidant enzymes, CAT and SOD make two antioxidant enzymes work together against oxidative damage. In a recent study, DEN administration to 5 weeks old Wistar rats was shown to result in decreased CAT activity (23). On the other hand, it was demonstrated that at early stage of DEN and PB administration CAT activity increased in liver (19). Consistent with these studies $(19,23)$, in our study, while blood CAT activity decreased in DEN+PB group, liver CAT activity increased, yet this increase was not statistically significant. In our study, blood SOD and CAT activities in DEN+PB group, and unaltered liver SOD and CAT activities were found to be in parallel, suggested that while at that time period blood ROS levels might cause the depletion of antioxidant enzymes, yet liver still might have the capability to manage oxidative stress partially. The activity loss in SOD and CAT may result with the oxidation of macromolecules such as membrane phospholipids, proteins, and DNA (4). In the present study, increased ROS levels in the liver may probably evoke the MDA increase due to the unaltered liver SOD and CAT activity following DEN and PB distribution. Moreover, the reason for increased liver CAT activity in the DEN+PB group compared to the DEN group might be related to the reciprocal decrease in GSH levels in the same group. Although CAT and glutathione peroxidase (GPx) both catalyze $\mathrm{H}_{2} \mathrm{O}_{2}$, still GPx requires $\mathrm{GSH}$ additionally (34). Decreased GSH levels in DEN+PB group may probably be related to activity of GPx instead of CAT. Antioxidants, such as SOD and CAT, stand as the first line of the antioxidant defense against the both erythrocytes and liver derived oxidative stress (10).

A recent study evaluating the effects of HES on DEN induced hepatocarcinoma reported that HES increases CAT levels compared to DEN administered group (17). Moreover, different amounts of HES addition to the rats' diet, found to increase not only CAT activity but also SOD activity (3). In the current study HES administration also increased CAT and SOD activity which makes sense with the previous studies $(3,17)$. HES has been documented to exhibit anti-apoptotic properties (14). According to the current knowledge, the best explained anti-carcinogenic effect of HES is its strong antioxidant properties. In fact, HES has been stated to exert antioxidant properties and ROS scavenging activity via regulating the ERK/Nrf2 signaling pathway (24). Furthermore, Wan et al. (41) reported that HES shows inhibitory effects on apoptosis, oxidative stress, and inflammatory cell infiltration by increasing hem oxygenase-1 activity in acetaminopheninduced liver injury in mice.

GSH is a tripeptide that contains thiol groups and is one of the non-enzymatic antioxidant responsible for the antioxidant protection of the body (37). GPx catalyzes the conversion of $\mathrm{H}_{2} \mathrm{O}_{2}$ to water and oxygen in the presence of hydrogen donated by GSH (35). Banakar et al. (6), and Shaban et al. (35), have reported decreased levels of GSH following DEN and PB administration consistently to our study findings. Increased ROS formation as a result of DEN and PB metabolism might probably cause increased demand for GSH in the present study. Similarly to other flavonoids, HES is found in the blood as sulfate conjugate (14). In the current study, increased GSH levels following HES application is presumably related to increased demand for sulfate which might be subsequently utilized for the conjugation of HES. Moreover, lipophilic features of HES provide rapid and simple entry inside the cell. Therefore, HES might have induced the antioxidants in the liver cell (14). The onset of numerous ailments is indicated 
to be associated with increased ROS formation (43). It has been reported that $\mathrm{H}_{2} \mathrm{O}_{2}$ exposure may lead to apoptosis by activating ROS generation (4). Furthermore, DEN derived ROS formation has been revealed giving rise to apoptosis (46). HES, on the other hand, has been shown to have antiapoptotic properties, thanks to its' radical scavenging effects (46). In addition to these properties, HES has been reported to inhibit bile derived acid stimulated cell death in liver cells (5). On the contrary of its anti-apoptotic effects in normal cells, HES has been known to induce apoptosis in various tumors, due to the disrupted balance between oxidant and antioxidant status (44). The elevated apoptotic index found in this study after DEN and PB administration could be explained with increased ROS formation. Similarly to findings of Bai et al. (5), in our study HES blocked apoptosis after DEN and PB application. Even though in same study it has been indicated that solely administration of HES up to 50 $\mu \mathrm{mol} \cdot \mathrm{L}^{-1}$ inhibit apoptosis, in our study we found that 50 $\mathrm{mg} / \mathrm{kg} /$ day solely administration of HES induce not only apoptosis but also increased MDA levels in liver. Despite the fact that $50 \mathrm{mg} / \mathrm{kg} /$ day HES administration decreased liver apoptosis together with liver MDA levels in $\mathrm{DEN}+\mathrm{PB}+\mathrm{HES}$ group, which might be regarded as reducing effects of HES on liver injury, in normal cells 50 $\mathrm{mg} / \mathrm{kg}$ /day HES administration induced liver damage which is a limitation of our study.

In conclusion HES gives prominent inhibitory effects on liver injury due to its' strong antioxidant and anti-apoptotic properties. Moreover, improved hepatocellular architecture following HES administration is another beneficial effect of HES. All these findings suggest that HES could be utilized as an alternative therapeutic due to obtained major benefits. Further studies should be organized to shed light on the protective role and therapeutic activities of HES and similar flavonoids. Due to the limitation of the study, a further dose-dependent study should be organized to evaluate the effects of HES on the liver. Furthermore, disclosing the molecular mechanism of how HES enter cells might be beneficial for establishing the therapeutic potential of HES.

\section{Acknowledgements}

This paper presented in International Conference on Multidisciplinary, Engineering, Science, Education and Technology, 2018, Dubai.

\section{Financial Support}

This research was supported by a grant supplied from "Firat University Research Fund" (VF.16.22).

\section{Ethical Statement}

This study was carried out following the approval of the Regional Local Ethics Committee at University of
Firat, Faculty of Medicine (approval number: 0903201645/34).

\section{Conflict of Interest}

The authors declare that there is no conflict of interest.

\section{References}

1. Aebi H (1984): Catalase in vitro. Methods Enzymol, 105, 121-126.

2. Alirezaei M, Kheradmand A, Heydari R, et al (2012): Oleuropein protects against ethanol-induced oxidative stress and modulates sperm quality in the rat testis. Med $\mathbf{J}$ Nutrition Metab, 5, 205-211.

3. Aranganathan S, Nalini N (2009): Efficacy of the potential chemopreventive agent, hesperetin (citrus flavanone), on 1,2-dimethylhydrazine induced colon carcinogenesis. Food Chem Toxicol, 47, 2594-2600.

4. Aranganathan S, Panneer Selvam J, Nalini N (2009): Hesperetin exerts dose dependent chemopreventive effect against 1,2-dimethyl hydrazine induced rat colon carcinogenesis. Invest New Drugs, 27, 203-213.

5. Bai X, Yang P, Zhou Q, et al (2017): The protective effect of the natural compound hesperetin against fulminant hepatitis in vivo and in vitro. Br J Pharmacol, 174, 41-56.

6. Banakar MC, Paramasivan SK, Chattopadhyay MB, et al (2004): $1 \alpha, 25$-dihydroxyvitamin D3 prevents DNA damage and restores antioxidant enzymes in rat hepatocarcinogenesis induced by diethylnitrosamine and promoted by phenobarbital. World J Gastroenterol, 10, 1268-1275.

7. Basaiawmoit SP, Alam A, Sohkhlet M, et al (2016): Diethylnitrosamine (DEN) induced morphological and biomolecular changes in mouse liver mitochondria. Indian J Biochem Biophys, 53, 187-198.

8. Bennett CJ, Caldwell ST, McPhail DB, et al (2004): Potential therapeutic antioxidants that combine the radical scavenging ability of myricetin and the lipophilic chain of vitamin $E$ to effectively inhibit microsomal lipid peroxidation. Bioorg Med Chem, 12, 2079-2098.

9. Chavan S, Sava L, Saxena V, et al (2005): Reduced Glutathione: Importance of Specimen Collection. Indian $\mathrm{J}$ Clin Biochem, 20, 150-152.

10. Choi EJ (2008): Antioxidative effects of hesperetin against 7,12-dimethylbenz(a)anthracene-induced oxidative stress in mice. Life Sci, 82, 1059-1064.

11. Drury R (1983): Theory and Practice of Histological Techniques. J Clin Pathol, 36, 609.

12. Duran Y, Karaboğa İ (2020): Effect of hesperetin on systemic inflammation and hepatic injury after blunt chest trauma in rats. Biotech Histochem, 95, 297-304.

13. El-Serag HB, Rudolph KL (2007): Hepatocellular Carcinoma: Epidemiology and Molecular Carcinogenesis. Gastroenterology, 132, 2557-2576.

14. Erlund I (2004): Review of the flavonoids quercetin, hesperetin, and naringenin. Dietary sources, bioactivities, bioavailability, and epidemiology. Nutr Res, 24, 851-874.

15. Fathima MZ, Nainar M, Somasundaram I, et al (2018): Hinokitiol-ameliorated diethylnitrosamine-induced hepatocarcinogenesis through antioxidant mechanism in rats: In vitro and in vivo study. Asian J Pharm Clin Res, 11, 232-237. 
16. Ganeshpurkar A, Saluja AK (2017): The Pharmacological Potential of Rutin. Saudi Pharm J, 25, 149-164.

17. Gokuladhas K, Jayakumar S, Rajan B, et al (2016): Exploring the Potential Role of Chemopreventive Agent, Hesperetin Conjugated Pegylated Gold Nanoparticles in Diethylnitrosamine-Induced Hepatocellular Carcinoma in Male Wistar Albino Rats. Indian J Clin Biochem, 31, 171-184.

18. Guzel EE, Kaya N, Ozan G, et al (2018): The investigation of effect of alpha lipoic acid against damage on neonatal rat lung to maternal tobacco smoke exposure. Toxicol Reports, 5, 714-722.

19. Hussein UK, Mahmoud HM, Farrag AG, et al (2015): Chemoprevention of Diethylnitrosamine-Initiated and Phenobarbital-Promoted Hepatocarcinogenesis in Rats by Sulfated Polysaccharides and Aqueous Extract of Ulva lactuca. Integr Cancer Ther, 14, 525-545.

20. Kakehashi A, Inoue M, Wei M, et al (2009): Cytokeratin $8 / 18$ overexpression and complex formation as an indicator of GST-P positive foci transformation into hepatocellular carcinomas. Toxicol Appl Pharmacol, 238, 71-79.

21. Karaca G, Sözbilir N (2007): Dietilnitrozamin Verilen Ratlarda Alfa Lipoik Asidin Koruyucu Etkilerinin Araştırılması. Kocatepe Tıp Derg, 7, 11-17.

22. Kim JY, Jung KJ, Choi JS, et al (2004): Hesperetin: A potent antioxidant against peroxynitrite. Free Radic Res, 38, 761-769.

23. Owumi SE, Dim UJ, Najophe ES (2019): Diethylnitrosamine aggravates cadmium-induced hepatorenal oxidative damage in prepubertal rats. Toxicol Ind Health, 35, 537-547.

24. Parhiz H, Roohbakhsh A, Soltani F, et al (2015): Antioxidant and Anti-Inflammatory Properties of the Citrus Flavonoids Hesperidin and Hesperetin: An Updated Review of their Molecular Mechanisms and Experimental Models. Phyther Res, 29, 323-331.

25. Pari L, Shagirtha K (2012): Hesperetin protects against oxidative stress related hepatic dysfunction by cadmium in rats. Exp Toxicol Pathol, 64, 513-520.

26. Park J, Seo J, Lee J, et al (2015): Distribution of Seven NNitrosamines in Food. Toxicol Res, 31, 279-288.

27. Paula Santos N, Colaço A, Gil da Costa RM, et al (2014): $N$-diethylnitrosamine mouse hepatotoxicity: Time-related effects on histology and oxidative stress. Exp Toxicol Pathol, 66, 429-436.

28. Placer ZA, Cushman LL, Johnson BC (1966): Estimation of product of lipid peroxidation (malonyl dialdehyde) in biochemical systems. Anal Biochem, 16, 359-364.

29. Pradeep K, Mohan CVR, Gobianand K, et al (2007): Effect of Cassia fistula Linn. leaf extract on diethylnitrosamine induced hepatic injury in rats. Chem Biol Interact, 167, 12-18.

30. Pradeep K, Mohan CVR, Gobianand K, et al (2007): Silymarin modulates the oxidant-antioxidant imbalance during diethylnitrosamine induced oxidative stress in rats. Eur J Pharmacol, 560, 110-116.

31. Qintieri LQ, Bortolozzo S, Stragliotto S, et al (2010): Flavonoids Diosmetin and Hesperetin are Potent Inhibitors of Cytochrome P450 2C9-mediated Drug Metabolism in vitro. Drug Metab Pharmacokinet, 25, 466-476.

32. Samie A, Sedaghat R, Baluchnejadmojarad T, et al (2018): Hesperetin, a citrus flavonoid, attenuates testicular damage in diabetic rats via inhibition of oxidative stress, inflammation, and apoptosis. Life Sci, 210, 132-139.

33. Saraswati S, Alhaider AA, Agrawal SS (2013): Anticarcinogenic effect of brucine in diethylnitrosamine initiated and phenobarbital-promoted hepatocarcinogenesis in rats. Chem Biol Interact, 206, 214-221.

34. Seifried HE, Anderson DE, Fisher EI, et al (2007): $A$ review of the interaction among dietary antioxidants and reactive oxygen species. J Nutr Biochem, 18, 567-579.

35. Shaban NZ, El-Kersh MAL, El-Rashidy FH, et al (2013): Protective role of Punica granatum (pomegranate) peel and seed oil extracts on diethylnitrosamine and phenobarbitalinduced hepatic injury in male rats. Food Chem, 141, 15871596.

36. Shang N, Bank T, Ding X, et al (2018): Caspase-3 suppresses diethylnitrosamine-induced hepatocyte death, compensatory proliferation and hepatocarcinogenesis through inhibiting p38 activation. Cell Death Dis, 9, 558.

37. Sherif IO (2018): The effect of natural antioxidants in cyclophosphamide-induced hepatotoxicity: Role of Nrf2/HO-1 pathway. Int Immunopharmacol, 61, 29-36.

38. Spinardi-Barbisan ALT, Kaneno R, Marchesan Rodrigues MA, et al (2000): Lymphoproliferative response and $T$ lymphocyte subsets in a medium-term multi-organ bioassay for carcinogenesis in Wistar rats. Cancer Lett, 154, 121-129.

39. Sun Y, Oberley L, Li Y (1988): A Simple Method for ClinicalAssay of Superoxide Dismutase. Clin Chem, 34, 497-500.

40. Vitaglione P, Morisco F, Caporaso N, et al (2005): Dietary Antioxidant Compounds and Liver Health. Crit Rev Food Sci Nutr, 44, 575-586.

41. Wan J, Kuang G, Zhang L, et al (2020): Hesperetin attenuated acetaminophen-induced hepatotoxicity by inhibiting hepatocyte necrosis and apoptosis, oxidative stress and inflammatory response via upregulation of heme oxygenase-1 expression. Int Immunopharmacol, 83, 106435.

42. Waris G, Ahsan H (2006): Reactive oxygen species: Role in the development of cancer and various chronic conditions. J Carcinog, 5, 1-8.

43. Yadav AS, Bhatnagar D (2007): Chemo-preventive effect of Star anise in N-nitrosodiethylamine initiated and phenobarbital promoted hepato-carcinogenesis. Chem Biol Interact, 169, 207-214.

44. Zhang J, Song J, Wu D, et al (2015): Hesperetin induces the apoptosis of hepatocellular carcinoma cells via mitochondrial pathway mediated by the increased intracellular reactive oxygen species, ATP and calcium. Med Oncol, 32, 1-11.

45. Zhao X, Zhang JJ, Wang X, et al (2008): Effect of berberine on hepatocyte proliferation, inducible nitric oxide synthase expression, cytochrome P450 $2 E 1$ and $1 A 2$ activities in diethylnitrosamine- and phenobarbital-treated rats. Biomed Pharmacother, 62, 567-572.

46. Zhu C, Dong Y, Liu H, et al (2017): Hesperetin protects against $\mathrm{H2O}$-triggered oxidative damage via upregulation of the Keap1-Nrf2/HO-1 signal pathway in ARPE-19 cells. Biomed Pharmacother, 88, 124-133.

47. Ziech D, Franco R, Georgakilas AG, et al (2010): The role of reactive oxygen species and oxidative stress in environmental carcinogenesis and biomarker development. Chem Biol Interact, 188, 334-339. 